\title{
ROZWAŻANIA O KONTRREWOLUCJI. CZESKI OBÓZ KATOLICKI I JEGO SOJUSZNICY W WALCE Z RADYKAŁAMI HUSYCKIMI
}

\begin{abstract}
Abstrakt: Artykuł przedstawia działania zbrojne i polityczne obozu katolickiego w Czechach w latach dwudziestych i trzydziestych XV w. skierowane przeciw radykalnym stronnictwom husyckim i ich wojskom.

Słowa kluczowe: Czechy, rewolucja husycka, obóz katolicki, kontrrewolucja, stronnictwa radykalne, taboryci, utrakwiści, sobór bazylejski, Zygmunt Luksemburski.
\end{abstract}

Abstract: The article presents the military and political actions of the Catholic camp in Bohemia undertaken in the 1420s and 1430s against radical Hussite factions and their armed forces.

Keywords: Bohemia, Hussite revolution, Catholic camp, counter-revolution, radical factions, Taborites, Utraquists (Calixtines), Council of Basel, Sigismund of Luxembourg.

Przedstawiony poniżej tekst wymaga kilku wyjaśnień dotyczących niektórych pojęć, określeń i nazw istotnych dla naszej problematyki. W jej kontekście pojęcie kontrrewolucji odnosi się do działań skierowanych przeciw radykalnym odłamom ruchu husyckiego walczącym o urzeczywistnienie rygorystycznie pojmowanej powszechnej reformy chrześcijaństwa ${ }^{1}$. Mówiąc o wspólnotach radykalnych uwzględniamy przede wszystkim południowoczeskich taborytów (wspólnota wyznaniowa, formacja wojskowa i stronnictwo polityczne), wschodnioczeskich orebitów (zwanych tak od husyckiego wzgórza pielgrzymkowego o nazwie Oreb),

${ }^{1}$ W niniejszym artykule w znacznym stopniu nawiązuję do ostatniej części mej monografii: S. Bylina, Rewolucja husycka, t. 3: Kontrrewolucja i opór pokonanych, Warszawa 2016. Informacje i rozważania istotne dla omawianej niżej problematyki znaleźć można w pracach zarysowych sygnalizowanych w przyp. 2 oraz w dalej przytaczanych pracach szczegółowych. 
którzy po śmierci Jana Žižki, twórcy ich potęgi wojskowej, nazwali siebie Sierotkami, oraz mieszkańców Nowego Miasta praskiego, pozostających pod wpływem radykalnych kaznodziejów. Na mapie wyznaniowej Czech doby husyckiej odnajdujemy ponadto ideowo bliskie taborytom dwie niewielkie wspólnoty skupione wokół ośrodków miejskich na północy kraju: Žatca i Loun ${ }^{2}$. Również i one dysponowały własnymi siłami wojskowymi. O wszystkich tych wspólnotach nie bez uproszczenia i ze świadomością anachronizmu będziemy mówić jako o lewicy husyckiej. Husyckich radykałów łączyła z umiarkowanymi utrakwistami akceptacja ogólnohusyckiego programu czterech artykułów praskich ${ }^{3}$, dzieliła natomiast ich odmienna interpretacja.

Głównym, niejako naturalnym przeciwnikiem wspólnot radykalnych był w Czechach obóz katolicki, mający oparcie w Kościele powszechnym i we władcach ziem sąsiednich na czele z królem niemiecko-rzymskim Zygmuntem Luksemburskim. A przecież nie tylko czeski obóz katolicki przejawiał aktywny sprzeciw wobec prężnej ofensywy husyckich nowatorów. Do sił katolickich zbliżał się bowiem najbardziej umiarkowany i najbardziej skłonny do ugody odłam wewnętrznie podzielonego ruchu husyckiego. Nosiciele tych postaw, nie zrywając całkowicie z obozem reformy, zmierzali do szybkiego wygaszenia wojny domowej za cenę daleko idących kompromisów z Kościołem i jego świeckimi podporami. Będziemy o nich mówić jako o prawicy utrakwistycznej (lub kalisznickiej) ${ }^{4}$.

2 Zob. przede wszystkim: F. Šmahel, Husitská revoluce, t. 1-4, Praha 1993; idem, Dějiny Tábora, t. 1, cz. 1-2, České Budějovice 1989-1990; P. Čornej, Velké dějiny zemí Koruny české, t. 5: 1402-1437, wyd. 2, Praha-Litomysl 2010. Z prac wcześniejszych: F.M. Bartoš, Husitská revoluce, t. 1-2, Praha 1965-1966 oraz H. Kaminsky, A History of the Hussite Revolution, Berkeley-Los Angeles 1967. Praca J. Macka, Tábor v husitském revolučním hnutí, t. 1-2, Praha 1955, bardzo już przestarzała pod względem interpretacyjnym, zachowuje wartość materiałową. Schyłkowej fazie rewolucji husyckiej poświęcił cykl swych artykułów Josef Válka, w tym: Zikmund a husité. Jak zakončit (husitskou) revoluci, „Časopis Matice moravské” 128, 2009, s. 3-32 oraz Husitská revoluce a první pokusy o restauraci, „Časopis Matice moravské" 130, 2011, s. 3-27. Warto też przytoczyć obszerny zbiór artykułów: Husitské století, red. P. Cermanová, R. Novotný, P. Soukup, Praha 2014 i wreszcie mój zarys dziejów rewolucji i kontrrewolucji: Rewolucja husycka, t. 1-3, Warszawa 2011, 2015, 2016.

3 Odnośnie do czterech artykułów uchwalonych w Pradze w 1420 r. (przypominam w skrócie zawarte w nich postulaty: swobodne głoszenie słowa Bożego, komunia pod dwiema postaciami dla ludzi świeckich, ubóstwo kleru i pozbawienie go władzy świeckiej, karanie grzechów śmiertelnych) zob. F. Šmahel, Husitská revoluce, t. 2, s. 94-111.

${ }^{4}$ Określenia: utrakwiści i kalisznicy (w literaturze husytologicznej także kalikstyni) są w istocie równoznaczne, odnosząc się do ogółu zwolenników komunii pod dwiema postaciami, związanych z umiarkowanym nurtem husytyzmu. Jednakże, jak w poprzednich mych pracach, uznałem za celowe ich rozróżnienie: określenia „utrakwiści" używam w odniesieniu do kleru husyckiego tego kierunku, a czasem też szerzej, 
Kontrrewolucja antyhusycka w Czechach w latach dwudziestych i trzydziestych XV w. miała wielorakie i zmienne oblicza. Przede wszystkim przejawiała się w walkach zbrojnych, będących odpowiedzią przemocą na przemoc. Była jednak również wykorzystywaniem środków politycznych celem zdobycia przewagi $\mathrm{w}$ wojnie domowej, a ponadto operowała instrumentami perswazji i propagandy.

Obserwujemy wydarzenia i zjawiska rozgrywające się na wielu obszarach i frontach wojny domowej. W rozważaniach naszych odsuwamy nieco na plan dalszy zagadnienie udziału obcych interwencji, w tym zwłaszcza krucjat wkraczających zbrojnie ze znakiem krzyża na ziemie czeskich heretyków - husytów. Nie pominiemy jednak zagadnienia stosunku czeskich sił katolickich do obcych krzyżowców i ewentualnego współdziałania z nimi.

Kontrrewolucja antyhusycka lat dwudziestych i trzydziestych XV w. miała swych antenatów, aktywnych, choć jeszcze niesięgających po środki przemocy. Wypada się cofnąć do jesieni 1415 r., a więc do czasu niewiele późniejszego od śmierci Jana Husa na stosie w Konstancji. Wówczas to czeska (a mniej licznie i morawska) szlachta podjęła akcję pieczętowania listów protestacyjnych, przekazywanych następnie uczestnikom soboru konstancjańskiego ${ }^{5}$. Od akcji tej odwróciło się jednak nie tylko wiele jednostek, lecz także szlacheccy mieszkańcy niektórych regionów kraju. Co więcej, wspomniane zbiorowe przedsięwzięcie spotkało się z przeciwdziałaniem środowisk antyreformatorskich. Jego wyrazem stało się zawiązanie tzw. Ligi Katolickiej ${ }^{6}$ powstałej z inicjatywy arcybiskupa praskiego Konráda z Vechty, wspartej przez przedstawicieli wyższej i średniej szlachty czeskiej. W Lidze Katolickiej znalazły dla siebie miejsce możne i wpływowe jednostki, których część będzie można spotkać w późniejszych latach wśród czołowych adwersarzy husyckich stronnictw radykalnych. Omawiany związek powołano celem obrony wiary katolickiej i Kościoła w Czechach przed zagrożeniem ze strony wielce już dynamicznych zwolenników reform wyznaniowych. Jest to niemal wszystko, co o nim wiemy.

Dokonywał się podział szlachty czeskiej na grono stronników husytyzmu (dalekie jeszcze od tendencji rewolucyjnych) oraz na część przeciwną tendencjom reformatorskim. Przedstawiciele wyższej szlachty

w kontekście spraw wyznaniowych, natomiast termin „kalisznicy” odnoszę do ich świeckich współwyznawców i sojuszników, zwłaszcza w kontekście politycznym i militarnym (mówiąc najczęściej o szlachcie kalisznickiej).

${ }^{5}$ Zob. B. Zilynskyj, Stižný list české a moravské šlechty proti Husovu upalení, „Folia Historica Bohemica" 5, 1982, s. 195-231. Zob. F. Šmahel, Dějiny Tábora, t. 1, cz. 1, s. 205 nn.

6 Zob. F. Šmahel, Husitská revoluce, t. 2, s. 286 n. 
(„panowie”, „urodzeni panowie”), orientujący się ku jednemu z dwóch antagonistycznych wobec siebie nurtów ideowych i politycznych, pociągali za sobą bliską im i w różny sposób od nich zależną niższą szlachtę, która tylko w ograniczonym zakresie miała możliwość dokonywania własnych wyborów ${ }^{7}$. W większym stopniu możliwość ta dotyczyła członków średniej szlachty, to jest głównie rycerstwa.

Do podzielonego ideowo kraju odnosiły się manifestowane już wówczas ambicje Zygmunta Luksemburskiego, przyznającego sobie rolę duchowego patrona obozu katolickiego w Czechach. Zygmunt, król rzymski i węgierski, był wszak potencjalnym następcą swego brata Wacława na tronie czeskim, co uzasadniało jego ówczesne inicjatywy. Świadomy niepokojów, sporów i podziałów wyznaniowych w Czechach, wystosował w 1416 r. wezwanie do tamtejszych dostojników kościelnych i panów świeckich, a poprzez nich do wszystkich mieszkańców Czech i Moraw. Apelował w nim o wytrwanie w „starej wierze” przodków i w wierności Kościołowi świętemu, a zatem o porzucenie nowinek religijnych. Wzywał do wspomagania króla Wacława IV, „brata naszego drogiego" ", do przywrócenia ładu i pokoju w kraju oraz do troski o jego dobro. Apel Zygmunta Luksemburskiego skierowany z Konstancji do Czech jest dla nas o tyle godny uwagi, że zawarte $\mathrm{w}$ nim treści będą się pojawiać z oczywistymi modyfikacjami w znacznie już późniejszych wewnętrznych programach obozu katolickiego. Sam Zygmunt po swej hradczańskiej koronacji przeprowadzonej w 1420 r. w czasie oblężenia Pragi przez krzyżowców, nieuznawanej w obozie husyckim, w listach do swych czeskich stronników, niekiedy chwiejnych w postawach, przypominał o wierności należnej mu jako panu naturalnemu.

Podstawowe siły obozu katolickiego w Czechach osadzone były na wielkich kompleksach dóbr szlacheckich, położonych głównie (bo przecież nie wyłącznie) w południowych i zachodnich regionach kraju9. $\mathrm{Na}$ mapie wyznaniowo-politycznej Czech doby husyckiej odnajdujemy

7 Ibidem, t. 1, s. 285.

${ }^{8}$ „[--] wšak wieme dobře, kteraku jsú wieru naši předkové drželi a kterak sú na nás wznesli, w té staré wieře a při kostelu swatém my také ostaňme a nechajme wšech nowých nálezów", Documenta Mag. Johannis Hus, vitam, doctrinam, causam in Constanciensis consilio illustrantia, wyd. F. Palacký, Praha 1869, nr 98, s. 619-621, tu s. 620. Dla powyższej problematyki istotny artykuł: P. Bar, Prohusitská propaganda v písemnostech Zikmunda Lucemburského, „Český časopis historický” 114, 2016, 3, s. 614-649.

9 O czeskim obozie katolickim (głównie u schyłku rewolucji) zwięźle: P. Čornej, Lipanská křižovatka, Praha 1992, s. 52-57; idem, Velké dějiny, t. 5, s. 369 nn.; F. Kavka, Poslední Lucemburk na českém trůně, Praha 1998, s. 112-120. Nieco szerzej: S. Bylina, Rewolucja husycka, t. 3, s. 11-36. 
dwa najrozleglejsze obszary katolickie o względnie stabilnej zwartości, mimo spotykających je uszczerbków terytorialnych dokonywanych przez wojska husyckie.

W obozie katolickim poczesne miejsce przypadało domenie magnackiego rodu Rožemberków, najrozleglejszej w Czechach włości wielkoszlacheckiej, usytuowanej w południowej części kraju, graniczącej na południu z księstwami austriackimi. Oldřich Rožemberk, w latach rewolucji husyckiej pan dóbr rodowych, pierwszy wśród czeskich magnatów pod względem zamożności i znaczenia ${ }^{10}$, władał obszarem stosunkowo gęsto zaludnionym, dość silnie zurbanizowanym, z wieloma grodami warownymi, które - świadomy husyckiego zagrożenia - starał się modernizować i dozbrajać. Starania te objęły nie tylko ośrodki miejskie położone blisko północnych granic domeny, szczególnie narażonych na działania wojenne, lecz także Czeski Krumlow, świetną rezydencję rodową położoną w głębi „państwa rožemberskiego" ${ }^{11}$. Gdy w początku lat dwudziestych młody Oldřich wraz ze swym mentorem, wpływowym Čenkiem z Vartemberku, porzucił wcześniejsze proreformatorskie nastawienie i zajął stałe już miejsce w obozie katolickim, wówczas dobra jego poczęły odczuwać konsekwencje bliskiego sąsiedztwa z Taborem, głównym bastionem taborytów i z innymi ośrodkami tej ekspansywnej wspólnoty.

W razie wojennej potrzeby pan południa Czech mógł wystawić około 1000 zbrojnych pieszych i około 200 konnych. Wojsko swe powoływał spośród niższej szlachty, objętej wobec niego obowiązkiem lennym, spośród części stałych załóg grodowych, wreszcie korzystając z najemników własnych lub niekiedy udzielanych przez przyjaznego sąsiada Albrechta Habsburga, zięcia Zygmunta Luksemburskiego ${ }^{12}$.

Główną siłą obozu katolickiego w Czechach nie była jednak domena rožemberska, lecz tzw. landfryd pilzneński, wojskowo-polityczno-wyznaniowy związek zachodnioczeskiej szlachty, trzech miast (Pilzna, Stř́bra i Tachova), a początkowo także przełożonych dużych tamtejszych klasztorów cysterskich i joannickich ${ }^{13}$. Związek ten, pierwotnie powołany w celu

10 Postaci Oldřicha Rožemberka poświęciła monografię Anna Kubíková, Oldřich II. $z$ Rožmberka, České Budějovice 2004.

${ }_{11}$ Zob. szczegółową i bardzo sumienną pracę R. Šimůnka, Správní systém šlechtického dominia v pozdně středověkých Čechách. Rožmberská doména 1418-1472, Praha 2005.

12 Zob. P. Čornej, Velké dějiny, t. 5, s. 436; problem możliwości Oldřicha Rožemberka w tym zakresie (podobnie zresztą jak i innych panów katolickich) jest dyskusyjny. O systemie organizacyjnym wojska rožemberskiego zob. R. Šimůnek, op. cit., s. $272 \mathrm{n}$.

${ }^{13}$ Landfrydowi pilzneńskiemu sporo uwagi w różnych miejscach swej pracy poświęca Václav Bystrický, Západní Čechy v husitských válkách, České Budějovice 2013. Dość 
zapewnienia pokoju i ładu na niespokojnej w czasach Wacława IV ziemi pilzneńskiej, w 1420 r. został odnowiony dla orężnej walki z husytami, a zwłaszcza dla obrony regionu przed ich inwazją ${ }^{14}$. Stało się to przy wsparciu Zygmunta Luksemburskiego, którego zachodnioczeska szlachta uznawała za króla Czech.

Istotne znaczenie strategiczne miało korzystne położenie ziem landfrydu, od zachodu graniczącego z krajami niemieckimi (Bawarią i Palatynatem), od północy z czesko-niemieckim regionem chebskim (Chebsko), od wschodu zaś niejakim zabezpieczeniem była bliskość zamków należących do panów z regionów Podbrdsko i Rakovnicko. Sytuację raczej niekorzystną miał natomiast południowy obszar landfrydu, luźno zbliżony do ziem domeny rožemberskiej, ale też i do ziem taboryckich.

W latach dwudziestych XV w. landfryd pilzneński tworzyło kilkunastu przedstawicieli tamtejszych czołowych rodów szlacheckich, osiadłych głównie na rodowych zamkach. Prym wśród nich wiedli Švamberkowie ${ }^{15}$, z których dwaj bracia, Bohuslav i Hynek o przydomku Krušina, stali kolejno na czele związku i byli naczelnymi komendantami jego wojsk. Do najmożniejszych i najbardziej wpływowych należeli ponadto Gutštejnowie, Švíhovscy i Kolovratowie.

Po w miarę skutecznym odpieraniu wojennych wypraw husyckich we wczesnych latach rewolucji oraz po przebiegających ze zmiennym szczęściem bojach późniejszych, w połowie lat dwudziestych landfryd doznał istotnych strat, a najdotkliwszą z nich była utrata bogatego miasta Stř́bro, opanowanego przez taborytów. Członkowie związku pilzneńskiego postanowili go wówczas wzmocnić w duchu zacieśnienia wzajemnej współpracy, wzmożenia wewnętrznej dyscypliny i odpowiedzialności. W zapisie programowym wyrzeczono się „umów i jakichkolwiek przymierzy” „z nieprzyjaciółmi Kościoła świętego, miłościwego króla pana naszego dziedzicznego [oraz] z nieprzyjaciółmi całego chrześcijaństwa"16. Nietrudno w tym oświadczeniu znaleźć echa znacznie wcześniejszego, znanego nam

powierzchownie: Z. Beran, Landfrydní hnutív zemích České koruny, České Budějovice 2014. Oczywiście uwzględnić należy również przytaczane przeze mnie zarysy autorstwa Šmahela i Čorneja.

14 Listár královského města Plzně a druhdy poddánych osad, cz. 1: 1300-1450, wyd. J. Strnad, Plzeň 1891, nr 267, s. 301-302. Zob. V. Bystrický, op. cit., s. 109.

${ }^{15} \mathrm{Na}$ temat głównych rodów zachodnioczeskich zob. V. Bystrický, op. cit., s. 360 i inne. Zob. też J. Jánský, Páni ze Švamberka. Pětisetletá sága rodu s erbem labutě, Domažlice 2006.

16 „Nejprwe, aby žadný z nás swrchupsaných sobě s nepřátely církwe swaté, KM pána našého dědičného, wšeho křestanstwie, tudiež i našiemi napřátely umluw žadnych ani přimeřie nečinil ani měl", Archiv český, čili staré písemné památky české i moravské, wyd. F. Palacký, Praha 1844, nr 37, s. 259. 
przesłania Zygmunta Luksemburskiego do możnych czeskich. Wierność Kościołowi, wyznawanej w nim wierze oraz prawowitemu władcy, także w następnych latach pozostawały programem całego obozu katolickiego, choć nie we wszystkich okolicznościach jawnie deklarowanym.

Szczególną rolę w landfrydzie zachodnim odgrywało Pilzno, miasto zamożne, leżące na ważnym szlaku handlowym, wyposażone w dobrze zbrojną załogę, znakomicie fortyfikowane. Po przejęciu z rąk Žižkowych pretaborytów w początku 1420 r. Pilzno, wcześniej „Miasto-Słońce” husyckich radykałów, stało się ważnym obronnym ośrodkiem katolickiego zachodu Czech ${ }^{17}$. U schyłku rewolucji husyckiej w trakcie długotrwałego oblężenia przez siły zbrojne (tzw. wojska polne) bractw radykalnych (1433/1434 r.) stało się symbolem, heroicznym bastionem czeskiego katolicyzmu. Do tego ważnego epizodu schyłkowych dziejów landfrydu pilzneńskiego oraz do udziału orężnych sił tego związku w zmaganiach obozu katolickiego jeszcze powrócimy.

Wspomniany uprzednio region chebski, północny sąsiad landfrydu pilzneńskiego, był obszarem stosunkowo niewielkim, swe zaś znaczenie w czeskim obozie katolickim zawdzięczał dużemu miastu rządzonemu przez bogaty patrycjat niemiecki. Cheb, w odróżnieniu od ziem tego regionu należących do Czech, był miastem Rzeszy, wiernym Zygmuntowi Luksemburskiemu, który nie szczędził mu przywilejów. Uczestniczył w potencjale wojskowym obozu katolickiego, produkując sprzęt wojenny (łącznie z odlewaniem dział) oraz poprzez udzielanie pomocy w postaci oddziałów dobrze zbrojnego wojska. Z pomocy tej korzystały niektóre armie krucjatowe, dla których Chebsko bywało także jednym z terenów zbornych. Obóz katolicki korzystał ponadto w istotny sposób z pomocy Chebu jako sprawnie funkcjonującego ośrodka informacyjnego i wywiadowczego ${ }^{18}$.

Wschodnim sąsiadem regionu chebskiego było również katolickie, bardziej od niego rozległe Loketsko, z miastem i zamkiem Loket, stanowiącym jego centrum. Potencjał gospodarczy i militarny ziemi loketskiej znacznie ustępował regionowi chebskiemu.

Na niejednolitym wyznaniowo obszarze Czech wschodnich leżały rozrzucone zamki i dobra ziemskie kilku możnych przedstawicieli tamtejszej wyższej szlachty. Tworzyli oni tzw. stronnictwo opoczyńskie

17 O roli Pilzna, zwłaszcza u schyłku rewolucji husyckiej: M. Polívka, Plzeň v závěru husitské revoluce, w: J. Hejnic, M. Polívka, Plzeň v husitské revoluci, Praha 1987, s. 217-384. Zob. też V. Bystrický, op. cit., s. 175, 351.

18 Sytuację Chebu w dobie rewolucji husyckiej charakteryzuje František Kubů, Cheb $v$ době husitské, w: Soudce smluvený v Chebu, Cheb [1984], s. 105-129. Zob. też V. Bystrický, op. cit., s. $46 \mathrm{nn}$. 
(od nazwy zamku Opočno należącego do Jana Městeckiego), będące strukturą nieformalną ${ }^{19}$. Stronnictwo wierne Zygmuntowi i wrogie zwłaszcza husyckim bractwom radykalnym w pewnych okresach odznaczało się niezależnością polityczną od potęg katolickich w Czechach. Wyróżniającą się postacią w stronnictwie opoczyńskim był, obok Jana Městeckiego, Puta z Castolovic, pan dóbr w ziemi kłodzkiej, aktywny polityk darzony względami przez Zygmunta Luksemburskiego.

Zatrzymamy się jeszcze na krótko przy większych miastach królewskich, których przynależność do obozu katolickiego była trwała bądź tylko czasowa, przerwana przejściem w ręce husyckie. Jednym z najważniejszych były Czeskie Budziejowice, bogate miasto średniej wielkości, położone powyżej północnej granicy dominium rožemberskiego. Dzierżone przez Albrechta Habsburga drogą zastawu Zygmuntowego, Czeskie Budziejowice były miastem obronnym, mającym liczną załogę. Opierały się skutecznie zagrożeniom husyckim ${ }^{20}$.

Miastem obozu katolickiego, wyróżniającym się szczególnym charakterem oraz agresywnie antyhusycką postawą jego mieszkańców, była w początkach rewolucji Kutná Hora, słynna ze swych kopalń srebra, miejsce funkcjonowania mennicy królewskiej. Do antyhusyckiej roli Kutnej Hory jeszcze wrócimy.

Ważnymi, w znacznej części trwałymi bastionami antyhusyckiego oporu były zamki królewskie i szlacheckie. Wśród tych pierwszych prymat należał do monumentalnego Karlštejnu, wzniesionego w Czechach środkowych w czasach Karola IV. Strategiczny walor tego zamku opierał się na jego korzystnym dla obrony położeniu, potężnych murach oraz na licznej, dobrze wyćwiczonej załodze utrzymywanej przez Zygmunta Luksemburskiego ${ }^{21}$. Skutecznie odpierała ona uporczywe i długotrwałe husyckie oblężenia, w potrzebie zaś wspierała także inne wojska katolickie walczące $\mathrm{z}$ husytami.

Znaczna większość szlacheckich zamków aż do końca rewolucji pozostała w rękach katolickich, także wtedy, gdy blisko sąsiadowały one z terenami husyckimi ${ }^{22}$. Zawdzięczały to skutecznej obronie swych załóg oraz nagromadzeniu środków niezbędnych im do życia. W innych przypadkach zamki szlacheckie pozostawały nietknięte, gdyż husyci, nie widząc zagrożenia z ich strony, nie angażowali swych sił w ich zdobywanie.

${ }_{19}$ Zob. monografię M. Šandery, Zikmundovi věrní na českém severovýchodě. Opočenská strana $v$ husitské revoluci, České Budějovice 2005.

${ }^{20}$ Zob. m.in. P. Čornej, Lipanská křižovatka, s. 55 n.

${ }^{21} \mathrm{O}$ roli Karlštejnu zob. m.in. F. Šmahel, Husitská revoluce, t. 4, s. 17 nn.

${ }^{22}$ František Kavka, op. cit., s. 118, akcentuje przewagę liczebną zamków panów katolickich. 
Szlachta odgrywała niepodważalną rolę w obu obozach. Ocenia się przy tym, że większa część tej warstwy, bardzo zróżnicowanej pod względem zamożności i prestiżu, była związana z obozem katolickim. W odniesieniu do „urodzonych panów” historycy zauważają stosunkowo liczne podziały przebiegające także wewnątrz rodów ${ }^{23}$. Wśród tych, którzy zbliżyli się do husytów, ich związek z naczelnym programem czterech artykułów zapewne nierzadko bywał raczej deklaratywny niż opierający się na przekonaniu i ograniczał się do przyjmowania komunii pod dwiema postaciami. A przecież ci szlacheccy sojusznicy stanowili istotną siłę militarną, a po części i polityczną (na forum sejmów krajowych), nie tylko husyckiej Pragi, lecz i taborytów. Wspomniane dylematy wyznaniowe nie dotyczyły panów związanych z obozem katolickim. Ich przejścia do obozu wyznawców Kielicha bywały stosunkowo nieliczne, po części związane $\mathrm{z}$ dostaniem się do niewoli i chęcią odsunięcia od siebie przykrych konsekwencji wynikających z tej sytuacji. Drastyczny był casus Bohuslava ze Švamberka, zwierzchnika landfrydu pilzneńskiego, który po ujęciu przez taborytów stał się czynnym uczestnikiem ich bojów ${ }^{24}$.

Nasuwa się pytanie, czy przedstawiciele wyższej szlachty katolickiej oraz katolickiego rycerstwa istotnie byli „wierni Zygmuntowi”, jak to się czasem określa w literaturze przedmiotu ${ }^{25}$. Zapewne w większości przypadków Zygmunt był uznawanym władcą i polityczną ostoją stronnictwa katolickiego w walce $\mathrm{z}$ husytami. Na czeskich ziemiach katolickich był dawcą godności i przywilejów oraz autorytetem milcząco usprawiedliwiającym zabory mienia kościelnego dokonywane przez katolicką szlachtę. Słusznie mówi się o zarówno husyckiej, jak katolickiej sekularyzacji dóbr kościelnych $^{26}$ : ta ostatnia przebiegała zwykle pod pozorem zabezpieczania mienia kościelnego. Zapewne też niejeden z przedstawicieli wyższej szlachty liczył na fawory królewskie w przyszłości, po spodziewanym zwycięstwie strony katolickiej i po rzeczywistym objęciu tronu przez Zygmunta. Oldřich Rožemberski był jednym z bardzo nielicznych czeskich „urodzonych panów”, którzy przynajmniej częściowo prowadzili własną politykę nie zawsze zgodną z oczekiwaniami króla i wpływowej części obozu katolickiego. Względna niezależność Oldřicha polegała zwłaszcza na uchylaniu się pod różnymi pretekstami od czynnego

${ }^{23}$ O początkach podziału ideowego wśród szlachty czeskiej zob. F. Šmahel, Husitská revoluce, t. 1, s. 271. O tożsamości szlacheckiej zob. R. Novotný, Šlechta, w: Husitské století, s. 306.

${ }^{24}$ V. Bystrický, op. cit., s. 30 n., 360.

${ }^{25}$ Nawiązuję tu zwłaszcza do określenia Martina Šandery odnoszącego się do stronnictwa opoczyńskiego, zob. jego monografię, op. cit.

${ }^{26}$ F. Kavka, op. cit., s. 76. 
udziału jego wojska w walkach z husytami, a także na zawieraniu z taborytami czasowych rozejmów i przymierzy ku jawnemu niezadowoleniu Zygmunta. Spotykamy się wreszcie ze strony Oldřicha z różnymi próbami porozumień z umiarkowanym skrzydłem obozu husyckiego, wcześniej niż stało się to nieukrywaną częścią polityki stronnictwa katolickiego. Oldřich z Rožemberku postępowanie swe tłumaczył koniecznością chronienia swych dóbr przed najazdami taborytów.

Bardzo liczna niższa szlachta (ok. 3000 rodów w Czechach i na Morawach wobec ok. 90 czeskich i 15 morawskich rodów wielkoszlacheckich) także w większości znalazła się w obozie katolickim ${ }^{27}$. Wspomniane już jej uzależnienie od wyższej szlachty dotyczyło m.in. bardzo licznej ubogiej szlachty na katolickim zachodzie Czech. Inna była sytuacja drobnej szlachty na ziemiach opanowanych przez husytów, gdzie zwłaszcza młodzi szlachcice znajdowali dla siebie miejsca w szeregach wojsk spod znaku Kielicha. Niektórzy z nich, odznaczający się talentem w rzemiośle wojennym, a zarazem gorliwi w walce o zwycięstwo prawdy Bożej, robili szybkie kariery wojskowe, stając się dowódcami większych lub mniejszych oddziałów. W wojskach panów katolickich możliwości w tym zakresie były znacznie mniejsze. Ale i tu, na przykład w landfrydzie pilzneńskim, można było znaleźć przykłady awansu materialnego i wzrostu prestiżu całych rodów niższej szlachty w wyniku wyróżniającego się udziału ich członków w walkach z husytami ${ }^{28}$.

Wspominaliśmy już o niektórych, zwłaszcza większych, miastach królewskich niezdobytych przez husytów. Jednakże miasta katolickie nie zawsze były pewnym sojusznikiem katolickiej szlachty. O ile Pilzno, będąc członkiem zachodnioczeskiego landfrydu, wspólnie z nim uczestniczyło w zbrojnych zmaganiach, o tyle Czeskie Budziejowice, choć sporadycznie wspomagały Oldřicha Rožemberka, to nie wyrzekały się zadawnionych z nim konfliktów. Ludność zwłaszcza niektórych miast katolickich zwiększała się wraz z napływem banitów i uciekinierów uchodzących z ziem będących we władaniu husytów. Szukali schronienia Niemcy wygnani z Pragi i z innych miast czeskich, katoliccy mieszczanie i katolicka szlachta obu nacji oraz nader licznie kler diecezjalny i zakonny oporny wobec przyjęcia nowego wyznania (zresztą z tej alternatywy nie zawsze mógł korzystać, stając się ofiarą husyckiej przemocy) ${ }^{29}$. Część emigrantów przywoziła

${ }^{27}$ F. Šmahel, Husitská revoluce, t. 1, s. 262, 279. Odnośnie do liczebności niższej szlachty w regionie pilzneńskiej zob. V. Bystrický, op. cit., s. 41.

${ }^{28}$ V. Bystrický, op. cit., s. 42.

${ }^{29}$ O sytuacji kleru, zwłaszcza zakonnego, w latach rewolucji husyckiej zob. m.in. P. Čornej, Velké dějiny, t. 5, s. 387 nn. Zob. także J. Kadlec, Přehled církevních dějin českých, t. 1, Praha 1977. 
ze sobą pieniądze i wartościowe przedmioty deponowane w miejscach tymczasowego, jak sądzili, wygnania. Ten ograniczony przecież napływ środków materialnych tylko w niewielkim stopniu mógł zmniejszać ciężar kosztów ponoszonych przez miasta w warunkach wojny domowej. Miasta katolickie utrzymywać wszak musiały zbrojne załogi wojskowe, a nie zawsze można było liczyć na wsparcie ze strony Zygmunta Luksemburskiego ${ }^{30}$. Niemało też kosztów pociągało za sobą zapewnienie miastu odpowiedniego stanu obronnego. Nie brakło doświadczeń skłaniających do dużego wysiłku w tej dziedzinie; oblężenia taboryckie (a także i praskie) mogły się kończyć okupem i wymuszonym wymarszem załogi, lecz wcale nierzadko wymordowaniem mieszkańców i to nie tylko obrońców - mężczyzn. Wyjątkową sytuację zapewnił sobie Cheb: rozrósł się i spotężniał dzięki stałej aktywności gospodarczej swych mieszkańców ${ }^{31}$.

Chłopi, do których umiejętności bojowych szlachta nie miała przekonania, w wojskach katolickich zajmowali raczej podrzędne miejsce, oczywiście nieporównanie niższe, nie tylko od zajmowanego przez ciężkozbrojne rycerstwo zwane „żelaznymi pannami”, ale i od ubogiej lennej szlachty. Inna była sytuacja chłopów w wojskach taboryckich, których potencjał militarny opierano na chłopskiej piechocie walczącej okutymi cepami, bronią łatwą do opanowania ${ }^{32}$.

W początkach rewolucji husyckiej chłopi ze wsi rožemberskich, świadomi możliwości poprawy swej sytuacji, uciekali na Tabor, do miast i wsi taboryckich, a najchętniej w szeregi „bożych wojowników”. W latach późniejszych, już u schyłku wojny domowej, gdy pogorszyła się sytuacja wsi taboryckich oraz materialna sytuacja wojska, część poddanych rožemberskich wracała do swych dawnych panów ${ }^{33}$.

Przynajmniej od czasu odparcia pierwszej krucjaty w 1420 r. po wczesne lata trzydzieste wojska husyckie zdobyły i utrzymywały przewagę nad siłami obozu katolickiego, odnosząc zwycięstwa w większości poważniejszych konfrontacji. W obozie katolickim świadomość tego stanu utwierdzały klęski kolejnych wypraw krzyżowych, pogrom

30 Zob. P. Čornej, Velké dějiny, t. 5, s. 436 n.

${ }^{31}$ F. Kubů, op. cit., s. 108 nn.

32 O sytuacji chłopów na czeskich ziemiach katolickich zob. F. Šmahel, Husitská revoluce, t. 4, s. 27 n. O udziale chłopów w wojnach husyckich w zestawieniu z sytuacją w wojskach katolickich zob. W. Iwańczak, Chłopi w średniowiecznym wojsku czeskim, w: Kościót - kultura - społeczeństwo. Studia z dziejów średniowiecza i czasów nowożytnych, red. nauk. S. Bylina, Warszawa 2000, s. 241-249.

${ }^{33}$ Nieprzystosowanie do życia w warunkach taboryckich niekiedy przyczyniało się do znacznie wcześniejszego powrotu - zob. Prameny k dějinám Táborska 1412-1424, wyd. R. Nový, „Táborský archiv” 2, 1989, s. 67-120. 
interwencyjnych wojsk niemieckich pod Ústí, wreszcie - już w końcowej fazie rewolucji - zwycięskie wyprawy husytów na sąsiednie ziemie katolickie, zwłaszcza na ziemie niemieckie. Wcześniej, w okresach szczytowych powodzeń wojsk husyckich, zdumiewać mogła szybkość i łatwość zdobywania katolickich dotąd miast.

Czeski mediewista Petr Čornej zauważył, że w latach rewolucji niemal nie dochodziło do wielkich bitew angażujących możliwie najpoważniejszy potencjał militarny obu stron ${ }^{34}$. Odnosi się to zwłaszcza do orężnych spotkań wojny domowej poprzedzających wielką bitwę pod Lipanami (1434). Od wielkich zbrojnych konfrontacji obie strony powstrzymywała konieczność wojskowego zabezpieczenia zajmowanych terenów i pewnie też niechęć do podejmowania zbyt wielkiego ryzyka.

Sukcesy wojsk husyckich odnoszone w bitwach na otwartym polu i w wyniku oblężeń umocnionych obiektów nieprzyjacielskich nie groziły jednak zajęciem największych zwartych obszarów katolickich. Utrzymał swój byt landfryd pilzneński mimo ponoszonych strat (zdobycie przez husytów Stř́bra i Tachova) i mimo niepowodzeń (długotrwałe oblężenie Pilzna). Zachowanie integralności wielkich katolickich terytoriów było możliwe dzięki skierowaniu głównego wysiłku militarnego na ich obronę.

$\mathrm{W}$ walkach sił obozu katolickiego $\mathrm{z}$ wojskami husyckimi dominowały działania defensywne, wynikające przede wszystkim z konieczności obrony własnych ziem przed ekspansywnymi działaniami taborytów, orebitów (zwanych po śmierci Žižki w 1424 r. Sierotkami) i wojsk praskich. Oddziały katolickie również wyruszały w pole, czasem nawet dość daleko od własnych granic, lecz w odpowiednim miejscu przerywały swój marsz, oczekując spodziewanego nadejścia wroga.

Wśród sił obozu katolickiego oddziały panów landfrydu pilzneńskiego współdziałały ze sobą bez większych zakłóceń. Natomiast w szerszej skali tego obozu sprawa przedstawiała się mniej korzystnie. Zwłaszcza Oldřich Rožemberk, który nie kwapił się do podejmowania własnych poważniejszych akcji antyhusyckich ${ }^{35}, \mathrm{w}$ miarę możliwości uchylał się także od współdziałania z innymi siłami katolickimi. Zabrakło sił rožemberskich w krwawej bitwie z wojskami Žižki pod Malešovem (1424 r.), w której porażkę poniosły wojska praskie oraz doraźnie z nimi sprzymierzone oddziały katolickiej szlachty ${ }^{36}$. W 1427 r. dowódcy wojsk landfrydu

34 P. Čornej, Velké dějiny, t. 5, s. 438 n.

${ }^{35}$ Wpływ na to zapewne miało całkowite fiasko oblężenia Taboru przez wojska rožemberskie, podjętego w 1420 r. pod wpływem Zygmunta Luksemburskiego, zob. F. Šmahel, Husitská revoluce, t. 3, s. 43 nn.

${ }^{36}$ Zob. Staréletopisy české, wyd. A.M. Černá, P. Čornej, M. Klosová, Fontes Rerum Bohemicarum, Series nova, t. 2, Praha 2003, s. 27. Zob. F. Šmahel, Husitská revoluce, t. 3, s. 149 n. 
pilzneńskiego, współdziałających wówczas z siłami kolejnej krucjaty, daremnie domagali się od Oldřicha Rožemberka wsparcia w postaci zatrzymania wojsk taboryckich spodziewanych w trakcie próby odzyskania zdobytego wcześniej przez husytów Stř́ibra ${ }^{37}$. W pewnych sytuacjach czeski magnat nie mógł już uchylać się od współdziałania, chcąc pozostawać wiernym i cenionym poddanym Zygmunta Luksemburskiego i oddanym Kościołowi panem katolickim. Wówczas, osobiście nie wyruszając w pole, wysyłał swe, czasem wcale liczne, oddziały dowodzone przez jednego $\mathrm{z}$ doświadczonych komendantów rožemberskich.

Jeszcze przed połową lat dwudziestych poważnemu wzmocnieniu uległ potencjał militarny sił stronnictw radykalnych. Bractwa taboryckie i ,sieroce" powołały nową formę organizacyjną swych sił zbrojnych w postaci tzw. wojsk polnych ${ }^{38}$. W odróżnieniu od wojsk powoływanych wcześniej, formacja ta miała charakter mobilny, przystosowywany do dalekich wymarszów, a ponadto była wojskiem stale pozostającym pod bronią. Tego rodzaju formacji wojskowych obóz katolicki nigdy nie powołał ${ }^{39}$.

O współdziałaniu czeskich sił katolickich z wojskami kolejnych wypraw krzyżowych mamy niewiele wiarygodnych informacji. Ogólnie biorąc, zdają się one wykluczać zjawisko szerszego współdziałania angażującego znaczną część wojsk katolickich. Także w przypadku pierwszej wyprawy krzyżowej pod wodzą Zygmunta Luksemburskiego (z którą katolicy mogli łączyć nadzieje na pokonanie husytów) przejawy poparcia dla krzyżowców miały charakter ograniczony: oblężenie husyckiej Pragi mimo udziału kilku czeskich panów z ich wojskami było najazdem obcego rycerstwa. Jeszcze skromniej przedstawiała się pomoc udzielana krzyżowcom w czasie następnych wypraw. Pewien wyjątek stanowiła pod tym względem krucjata z 1427 r., gdy do działań krzyżowców w zachodnich Czechach przyłączyły się oddziały landfrydu pilzneńskiego, widzące w tym własne cele (odzyskanie Stř́bra i Tachova) ${ }^{40}$.

Do wspierania wojsk krzyżowych czeskie siły katolickie zniechęcały przede wszystkim klęski kolejnych interwencji. Innym negatywnym czynnikiem bywały zniszczenia dokonywane przez krzyżowców w czasie ich przemarszów przez ziemie czeskie, dotkliwe także dla dóbr panów katolickich. W niektórych przypadkach dochodziło do nader drastycznych nieporozumień między tymi, którzy w zasadzie walczyli ze wspólnym wrogiem.

37 Listář a listinář Oldřicha z Rožmberka, wyd. B. Rynešová, t. 1: 1418-1437, Praha 1929, nr 138, s. 93-94.

38 Zob. ostatnio: R. Novotný, Polní vojska, w: Husitské století, s. 131-148.

39 Zob. P. Čornej, Velké dějiny, t. 5, s. 436.

${ }^{40}$ V. Bystrický, op. cit., s. 309 nn. 
Krzyżowcy mogli natomiast liczyć na wsparcie zamieszkującej Czechy ludności niemieckiej. Wprawdzie niemieccy wygnańcy i uciekinierzy rozproszeni po Czechach katolickich nie stanowili realnej siły, lecz, jak już wspomniano, liczącą się w walkach siłę stanowił przygotowany do wysiłku wojennego Cheb. We wczesnej zaś fazie wojny domowej sprzyjała Zygmuntowi gorliwie antyhusycka Kutná Hora, zamieszkała wówczas, zanim nie przeszła w ręce husytów, przez ludność niemiecką. We wczesnych latach dwudziestych Kutná Hora była jednym z ważniejszych punktów oporu strony katolickiej, czasową rezydencją Zygmunta Luksemburskiego, schroniskiem licznych emigrantów etnicznych i wyznaniowych, w tym Niemców zbiegłych z Pragi, była wreszcie miejscem spontanicznego i zaciekłego represjonowania husytów i ich sympatyków ${ }^{41}$. Kutnohorscy górnicy, wydobywający srebro w tamtejszych kopalniach, zasłynęli jako gorliwi i wyrafinowani zabójcy husytów, ujętych jeńców, podobno wykupywanych również od wojsk katolickich ${ }^{42}$. Źródła kronikarskie oraz ikonografia utrwaliły motyw ścinania głów ofiarom i wrzucania ich ciał do nieczynnych już szybów górniczych. Egzekucjom towarzyszyć miały jakieś rytuały, odnotowano także szyderczą nazwę „Tabor”, nadaną przez kutnohorskich górników jednemu z głębokich szybów ${ }^{43}$, który stał się zbiorowym grobem mordowanych husytów. Kutná Hora z pewnością była szczególnym miejscem eksplozji nienawiści wobec wrogów wyznaniowych, etnicznych i politycznych, ale wypadnie też wspomnieć o Litomierzycach, gdzie również spontanicznie topiono husytów w nurtach Łaby ${ }^{44}$. Gdy Kutná Hora została zdobyta przez husytów i gdy do miasta wkroczył Jan Žižka ze swym wojskiem, mieszkańcy miasta witali go uroczyście, lecz uczestnicząc we mszy taboryckiej, odprawianej przez brodatych księży bez ornatów, nie kryli swego oburzenia ${ }^{45}$.

${ }^{41}$ Zob. zwłaszcza: J. Kejřr, Právnický život v Kutné Hoře, Praha 1958, s. 15-33.

${ }^{42}$ Ibidem, s. 20.

43 ,[-- quos Montani, Theutunici, Boemorum et presertim veritatis Christi diligencium crudeles persecutores et inimici, variis blasphemiis et sachtas nocturnis presertim temporibus inhumaniter iactabant, quosdam viros, quosdam vero decollatos, et precipue ad sachtam sancti Martinis foris valvam Curimensem vicinam, quam Thabor Montani vocaverunt", Vavřinec z Březové, Kronika husitská, wyd. J. Goll, Fontes Rerum Bohemicarum, t. 5, Praha 1893, s. 352.

${ }^{44}$ Zob. J. Smetana, K počátkům husitství v Litoměřicích, „Vlastivědný sborník Litoměřicka" 11, 1974, s. 39-79.

${ }^{45}$ Vavřinec z Březové, op. cit., s. 529-530, dość szczegółowo opisuje mszę taborycką, w tym sposób udzielania komunii wiernym, po czym dodaje, s. 530: „[--] hoc videntes utriusque sexus Montani amplius in Boemie scandalisati spuentes in terram cum murmuracione de ecclesia recesserunt [--]". 
W wojskach katolickich nie brakło dowódców wyróżniających się swymi umiejętnościami. Należał do nich zwierzchnik całego landfrydu pilzneńskiego Hynek Krušina, brat Bohuslava, który wolał przejście na stronę wroga od niewoli i z pewnością wysokiego okupu. W domenie rožemberskiej Oldřicha, bardziej polityka niż wojownika, godnie zastępował w działaniach bojowych dowódca tamtejszych wojsk, Mikuláš Krchlebec $^{46}$. Bez wątpienia nieprzeciętną postacią był doświadczony komendant Karlštejnu Zdislav Tluksa z Buřenic ${ }^{47}$. Można byłoby wymienić jeszcze kilku dowódców sprawnie kierujących wojskami katolickimi. A przecież w obozie tym brakło jednostek na miarę nie tylko wybitnych hetmanów husyckich: Jana Žižki i Prokopa Łysego, lecz także porównywalnych do niektórych wybijających się dowódców wojsk praskich z czasów ich tryumfów. Oczywiście przyczyny tego mogły być zróżnicowane. Pewien wpływ mógł mieć przeważająco defensywny charakter działań zbrojnych wojsk katolickich. Ponadto ich dowódcy nie otrzymywali możliwości dowodzenia wielkimi jednostkami, takimi, jakimi były wojska polne taboryckie i „sieroce” w latach ich potęgi. Wreszcie warto wziąć pod uwagę znacznie bardziej ograniczoną możliwość wspinania się po stopniach kariery wojskowej niż miało to miejsce w wojskach husyckich.

Niektórzy z katolickich dowódców wojskowych przejawiali znaczne zdolności dyplomatyczne, z pewnością nie mniejsze niż cechujące dowódców husyckich. Orężne starcia sił sobie wrogich nie mogły, co zrozumiałe, trwać nieprzerwanie na wszystkich frontach wojny domowej. Wtedy, gdy obie strony uznawały to za korzystne, zawierano rozejmy na czas określony. Dowódcy husyccy próbowali łączyć ich warunki $\mathrm{z}$ naciskami o charakterze ideowym. Dowódcom katolickim wymagania tego rodzaju bywały raczej obce. W ramach rozejmów domagali się prawa zakupu żywności na terenach zajętych przez przeciwnika, względnie w szczególnych sytuacjach zgody na pokojowy przemarsz własnych wojsk.

Obóz katolicki w Czechach nie miał na swych ziemiach wybitnych przywódców duchowych. Autorytet arcybiskupa praskiego Konrada z Vechty zmienił się wśród katolików w niechęć i pogardę, gdy przyjął on utrakwizm $(1421)^{48}$, zresztą nie zyskując przez to szacunku husytów, zwłaszcza ich radykalnych odłamów. Przeniesienie wyższych instancji czeskiego Kościoła katolickiego do Ołomuńca ${ }^{49}$ podniosło prestiż

\footnotetext{
${ }^{46}$ A. Kubíková, op. cit., s. 82.

47 F. Šmahel, Husitská revoluce, t. 4, s. 16-18.

48 Vavřinec z Březové, op. cit., s. 478.

${ }^{49}$ Zob. F. Šmahel, Husitská revoluce, t. 4, s. 8 nn.; P. Čornej, Velké dějiny, t. 5, s. 387.
} 
biskupów ołomunieckich. Późniejszy kardynał Jan Železný, bliski Zygmuntowi Luksemburskiemu, nie zdobył jednak sobie szerszego uznania. Rola kleru średniego i niższego szczebla na katolickim zachodzie i południu Czech ograniczała się do wypełniania przezeń zwykłych obowiązków duszpasterskich i chyba trudno byłoby nam dostrzec wybijające się tam jednostki.

Skrajnym antyhusytyzmem i nastawieniem antyreformatorskim wyróżniali się w obozie katolickim księża emigranci, zwolennicy generalnej restauracji stosunków kościelnych doby przedhusyckiej ${ }^{50}$. Byli też konsekwentnymi przeciwnikami jakiejkolwiek ugody Kościoła z husytami. Duchowni ci, wyrwani ze swych dawniejszych środowisk, pozbawieni swych pozycji i dochodów, nie mogli liczyć na zyskanie poważniejszych wpływów.

Brakło wprawdzie w obozie katolickim wybitnych kaznodziejów i agitatorów, lecz nie brakło ludzi pióra, którzy swą aktualną twórczość, w większości niewysokiego lotu, wymierzali przeciw czołowym postaciom ruchu husyckiego i przeciw jego wspólnotom ${ }^{51}$. Pierwsza fala tego zaangażowanego piśmiennictwa ujawniła się niedługo po śmierci Husa, a więc na kilka lat przed rewolucją husycką. Zachowała się jedynie pewna część utworów rymowanych i prozatorskich wyrażających poglądy ich autorów w różnych formach satyr, inwektyw, parodii itd. W utworach tych, w większości pisanych w języku czeskim, wyszydzano praskich i prowincjonalnych wyznawców nauki Husa, wędrownych agitatorów oraz możnych popleczników ruchu reformatorskiego, takich jak wspomniany już Čeněk z Vartemberku, plenipotent Rožemberków.

Szerszy odbiór społeczny zapewne można przypisać antyhusyckim pieśniom (a przynajmniej ich łatwym do zapamiętania fragmentom). W tonie szyderczo-gniewnym oskarżano husytów o bezlitosną przemoc, świętokradztwo, łamanie przykazań Bożych. Wyszydzano prostych adeptów husytyzmu, którzy, otumanieni przez wymownych i przewrotnych kaznodziejów, uwierzyli w swą jakże w istocie nikłą wiedzę i sami zaczęli szerzyć błędne nauki. W piśmiennictwie antyhusyckim zadomowił się wówczas motyw „szewców i krawców”, zarozumiałych prostaków,

${ }^{50}$ Chociaż postawy bywały jednak zróżnicowane, zob. J. Kadlec, Czeska katolicka emigracja okresu husytyzmu na ziemiach polskich i na Śląsku, „Zeszyty Naukowe Katolickiego Uniwersytetu Lubelskiego" 19, 1976, 4, s. 27-36.

${ }^{51}$ Zob. nowsze zwięzłe zarysy dziejów w piśmiennictwie doby husyckiej: P. Čornej, M. Bartlová, Velké dějiny zemí Koruny české, t. 6: 1437-1526, Praha 2007, s. 304-336; J. Boubín, Pisemnictví, w: Husitské století, s. 490-518. Zob. też S. Bylina, Rewolucja husycka, t. 3, s. 89-111. 
przekonanych o tym, że w pełni posiedli prawdy Pisma Świętego, wcześniej zatajane przed wiernymi przez księży katolickich ${ }^{52}$.

Pod koniec lat dwudziestych omawiany nurt piśmiennictwa antyhusyckiego zaczął ustępować bądź to tekstom o charakterze traktatowym (o już z natury wąskim kręgu oddziaływania), bądź utworom literackim o bardziej wyważonej dydaktyce katolickiej, a przy tym pisanym w sposób łatwo dostępny dla czytelników świeckich. Należał do nich długi utwór wierszowany zatytułowany Václav, Havel a Tábor, będący trialogiem na temat aktualnych a jątrzących spraw wyznaniowych, a ściślej sporem między katolikiem Václavem, spokojnie i rozsądnie broniącym stanowiska Kościoła, a gwałtownym, brnącym w swe błędy husyckim radykałem Táborem ${ }^{53}$.

Brakuje podstaw do oceny rzeczywistego oddziaływania literatury antyhusyckiej w społeczeństwie czeskim. Jednym z godnych uwagi problemów jest poszerzenie kręgu zaangażowanego piśmiennictwa antyradykalnego (określenie „antyhusyckiego” nie byłoby tu właściwe) o autorów reprezentujących najbardziej ugodowe środowiska utrakwistyczne. Sygnalizowane zjawisko było symptomem stopniowego zbliżania się niektórych przedstawicieli tego nurtu, głównie praskich mistrzów uniwersyteckich, do obozu katolickiego.

Wczesne wojenne sukcesy Žižki i dowodzonych przez niego wojsk na głównym katolicko-husyckim froncie wojny domowej oraz jawna wrogość słynnego już hetmana wobec kalisznickiej Pragi i jej szlacheckich sojuszników zbliżyły do siebie niedawnych przeciwników: najbardziej ideowo i politycznie umiarkowanych husytów z katolicką szlachtą czeską i morawską ${ }^{54}$. W obozie katolickim tendencje do doraźnej ugody wiązały się zapewne również z obserwacją dotkliwych klęsk pierwszych krucjat: przestano wierzyć w możliwość zwycięstwa przy pomocy zagranicznych interwentów. Obie strony, mimo że je wiele dzieliło, łączył wspólny cel:pokonania lub przynajmniej politycznego unieszkodliwienia sił radykalnych.

Przyszła koalicja formowała się w ciągu około dziesięciolecia w różnego rodzaju wspólnych działaniach, głównie poprzez spotkania obu stron $^{55}$. W ich trakcie starano się określić wspólny program oraz środki

52 Zob. S. Bylina, Szewcy i krawcy w inwektywach i satyrze antyhusyckiej, w: Świat średniowiecza. Studia ofiarowane Profesorowi Henrykowi Samsonowiczowi, red. A. Bartoszewicz, Warszawa 2010, s. 734-744.

${ }^{53}$ Václav, Havel a Tábor, w: Veršované skladby doby husitské, wyd. F. Svejkovský, Praha 1963, s. 116-150.

54 Zob. P. Čornej, Tajemství českých kronik, Praha 1987, s. 170.

55 Obok cytowanej dalej literatury przedmiotu zob. S. Bylina, Rewolucja husycka, t. 3 , rozdz. „Porozumienia, umowy, koalicje”. 
zmierzające do unieszkodliwienia stronnictw radykalnych, m.in. poprzez odebranie im społecznego poparcia w sprzyjającej im części społeczeństwa. Frazeologia obrad, choć ich zapisy bywają nam znane jedynie fragmentarycznie, jest godna uwagi nie mniej niż podejmowane decyzje.

Jesienią 1423 r. na zjeździe w Kolínie, mieście należącym do związku miast praskich, ogłoszono mobilizację sił przeciw tym, których uznano za winnych całego zła ogarniającego ziemię czeską. Przedstawiciele czeskiej szlachty katolickiej i kalisznickiej utożsamiali owych „zatracicieli kraju” z Žižką i jego zwolennikami. Ogłoszono wyprawę wojenną przeciw wspólnym wrogom ${ }^{56}$; można w tym widzieć chwyt propagandowy włączony do kolińskiego manifestu. Wśród uczestników zjazdu spotykamy postaci z pierwszego szeregu czeskiej szlachty katolickiej, one też bez wątpienia nadawały ton obradom.

Inicjatywę współdziałania kalisznicko-katolickiego zarysowującą się w Kolínie podjął w znacznie szerszym wymiarze sejm krajowy zwołany w październiku 1423 r. do Pragi na dzień św. Gawła (stąd jego czeska nazwa „sněm svatohavelský” ${ }^{57}$. Sejm ten, w którym poza opieszałym Oldřichem Rožemberskim uczestniczyli eminentni przedstawiciele wyższej szlachty katolickiej i kalisznickiej, podjął główny wątek uchwał kolińskich. W zapisach obrad potwierdziły swoje kluczowe miejsce pojęcia przytaczane już wcześniej: „obecné dobro” (dobro powszechne) jako generalna wytyczna wszystkich postanowień oraz „zhubcie země” odnoszące się do wspólnych, tych samych co uprzednio wrogów. I tym razem mówiono o zaprzestaniu rozlewu krwi, o uzdrowieniu stosunków publicznych oraz o naprawie złej sytuacji materialnej kraju ${ }^{58}$. Te ogólnikowe postulaty nie mogły wzbudzać czyjegokolwiek sprzeciwu.

Mimo to język obrad zaskakuje swą, skądinąd zrozumiałą, niejednolitością. Obok wysuwanego przez szlachtę katolicką postulatu przemiany występków w powszechny ład („neřady w řad”), co mogło oznaczać przywrócenie porządku doby przedhusyckiej, pojawił się wyraźnie husycki postulat debaty nad czterema artykułami ${ }^{59}$.

${ }^{56}$ O zjeździe (nazywanym też sejmem) w Kolínie zob. I. Hlaváček, Husitské sněmy, „Sborník Historický” 4, 1956, s. 81. Zlomky tekstu postanowień kolińskich opublikowali: A. Fialová, Z. Hejnic, Český Krumlov v době husitské, „Sborník Národního muzea v Praze”, řada A - Historie 29, 1975, s. 20-21.

57 Zapis obrad i postanowień sejmu svatohavelskiego: Archiv český, t. 3, nr 31, s. 240-248. Podstawowa literatura przedmiotu: S. Bylina, Rewolucja husycka, t. 3, s. 63, przyp. 8.

${ }^{58}$ Archiv český, t. 3, nr 31, s. 241-242.

59 „Na kterémžto slvšení ty pravdy swaté mezi námi ohlašené aby mohli byty swobodně wyznany a písmem swatým stalejším doličeny a dokazany [--]”, ibidem, s. 241. 
Uchwały sejmu svatohavelskiego, mimo ich nader słabego oparcia w ówczesnej rzeczywistości, były dla obu stron ważnym doświadczeniem na drodze do przyszłej, już realnie funkcjonującej koalicji. Najistotniejszym z podjętych ustaleń był zarysowany program zasadniczej, swobodnej katolicko-kalisznickiej debaty wyznaniowej z udziałem teologów i laików reprezentujących obie strony ${ }^{60}$. Ustępstwa strony katolickiej dopuszczającej postulaty husyckie jako przedmiot debaty świadczyć mogą o potrzebie utrzymania nawiązanego porozumienia. W tekście, o którym mówimy, nie znajdujemy - co łatwo zrozumieć - wątków należących do wewnętrznego programu obozu katolickiego (sprawa obrony Kościoła i wiary katolickiej, wierność królowi Zygmuntowi). Odnosić się to będzie również do późniejszych zapisów porozumień husycko-kalisznickich.

Dla przywrócenia pokoju i ładu w Czechach powołano kolegialne ciało zwierzchnie złożone z dwunastu wymienionych imiennie przedstawicieli wyższej szlachty katolickiej i husyckiej („urozené pány strany jedné [--] a strany druhé [--]”)61. W tym „pańskim” rządzie krajowym (zabrakło w nim przedstawicieli utrakwistycznej Pragi) spotykamy jednostki, które w następnych latach umocnią swoje znaczenie jako politycy i wojskowi dowódcy obozu antyradykalnego. Można stwierdzić, że na sejmie praskim w 1423 r. powołano część kadry przyszłej koalicji.

Wyciszono głośne w Kolínie akcenty wojenno-konfrontacyjne, choć przecież nikt nie mógł wątpić, że warunkiem przywrócenia postulowanego pokoju i ładu w kraju musi być, wedle rzeczników powyższego programu, pokonanie tych, których uznano za generalnych winowajców i wrogów publicznych.

Decyzjom podjętym w Pradze, i tym razem niemającym szans urzeczywistnienia, sprzeciwił się Zygmunt Luksemburski, kierując się zarówno własnymi racjami, jak i podtrzymując aktualne wówczas stanowisko Kościoła62. Upadek koalicji „svatohavelskiej” nie udaremnił zabiegów o kontynuację celów i działań szlachty katolickiej i kalisznickiej. Wojenne przewagi sił radykalnych skłoniły stronę przeciwną do poszukiwań pokojowych środków zakończenia rewolucji. W trakcie rokowań w miejscowości Zdíce wyrzeczono się używania nawet stonowanego języka konfrontacji, przywołując treści mające wyrażać stanowisko ponad podziałami. Znów więc mówiono o „powszechnym dobru” jako nadrzędnym, wspólnym

60 Ibidem, s. 241-242.

${ }^{61}$ Ibidem, s. 242.

${ }^{62}$ List Zygmunta Luksemburskiego do Oldřicha: Listár̆ a listinář Oldřicha z Rožmberka, t. 1 , nr 97, s. 69 . 
dla obu stron celu działania ${ }^{63}$. Akcentowano potrzebę zastąpienia walk i waśni powszechną zgodą, postulowano wreszcie „oczyszczenie tej ziemi czeskiej z fałszywych oskarżeń"64. Motyw ten odwoływał się do pamięci czeskiej szlachty reformatorskiej, która przed laty, po śmierci Jana Husa, żądała oczyszczenia Królestwa Czeskiego z niesławy rozpowszechnianej przez obcych. W Zdícach powrócono do wysuniętej na sejmie praskim koncepcji katolicko-husyckiej debaty wyznaniowej, przy czym głos rozstrzygający powierzono reprezentującym obie strony ludziom świeckim $^{65}$. „Umowy zdíckie”, idące drogą wzajemnych ustępstw, mogą być uznane za arcydzieło dyplomacji w dziedzinie kontynuacji porozumienia i poszukiwania tego, co jest możliwe do przyjęcia, lecz nadal nie uwzględniały realiów czasu, w którym rewolucja nie poddawała się tendencjom zmierzającym do jej wygaszenia. Tym bardziej że po śmierci Žižki nastąpiło wzajemne zbliżenie stronnictw radykalnych, a powołane przez nie do życia wojska polne stały się potęgą długo jeszcze niezwyciężoną.

Kolejna propozycja katolicko-husyckiej debaty wyznaniowej nadeszła w 1427 r. ze strony katolickiej szlachty zachodnioczeskiej ${ }^{66}$. Tym razem zwrócono się w pierwszym rzędzie już nie do prawicowego skrzydła stronnictwa utrakwistycznego, lecz dowódców (hejtmané) i „starszych” wojsk taboryckich i sierocych oraz do szlacheckich sojuszników obu bractw radykalnych. Mieli się oni stać współorganizatorami (a po części i uczestnikami) debaty prowadzącej do ustania „waśni między nami i przelewu krwi" ${ }^{67}$. Dodajmy, że świeccy przywódcy taborytów i Sierotek, do których się zwrócono, reprezentowali wówczas stanowiska umiarkowane. Dotyczyło to także Prokopa Łysego, późniejszego dowódcy wojsk taboryckich w rozstrzygającej walce z siłami koalicji. Wśród husyckiej szlachty wymienionej w programowym tekście spotykamy sojusznika taborytów, możnego Menharda z Hradca, pana Velhartic, później niekwestionowanego przywódcę koalicji. Spotykamy tam także inne osobistości,

${ }^{63}$ Tekst tzw. umów zdíckich: Archiv český, t. 3, nr 33, s. 245-251. O sejmie w Zdícach zob. m.in. F. Šmahel, Husitská revoluce, t. 3, s. 152 nn. Zob. też J. Válka, Zikmund a husité, s. $18 \mathrm{n}$.

${ }^{64},[--]$ wšichni wespole k tomu patřiece, kudyby táto koruna Česká bohda newinně zhyžděná a nařcena bezpráwně. Od takowých neřádných powěsti i ohyzd o naroków nejpoctiwěji mohla očiščená býti [--]", Archiv český, t. 3, nr 33, s. 248.

65 Ibidem, s. 249.

${ }^{66}$ Umowa w sprawie zjazdu na zamku Žebrák: Archiv český, t. 3, nr 39, s. 264-267. Zob. V. Bystrický, op. cit., s. 248.

${ }^{67}$ „A tu když se sjedú, maji spolu o ty wěci, o ktérež smy rozdieleni mezi sebú, bratrsky z písma swatého mluwili, zdaliby s pomoci pana boha wšemohuciego mohli se sami sjednati a mezi nami tyto swary a krwe prolewanie stawiti”, Archiv český, t. 3, nr 39, s. 265. 
które w następnych latach miały porzucić stronnictwa radykalne lub wręcz je zdradzić. Być może część z nich była już wówczas skrytymi stronnikami obozu katolickiego. Planowana debata na zamku Žebrák tym razem istotnie doszła do skutku, lecz z nieznanych nam bliżej przyczyn została przerwana ${ }^{68}$.

Zakończyć rewolucję! - to hasło sterowało poczynaniami uczestników wszystkich bardziej lub mniej realnych porozumień i skłaniało do formułowania deklaracji, które w innych sytuacjach z pewnością byłyby odrzucane. Działania koalicyjne obierały jednak czasem drogi dalekie od rozwiązań kompromisowych i politycznych.

Do takich właśnie przedsięwzięć należała próba przywrócenia w Pradze ładu towarzyszącego rządom Zygmunta Korybutowicza, skłaniającego się ku skrywanym porozumieniom z Kościołem i monarchiami katolickimi, a obalonego przez centrum husyckie wiosną $1427 \mathrm{r} \cdot{ }^{69}$ Spisek zawiązany w Kolínie opierał się na współdziałaniu prawicy kalisznickiej z czołowymi przedstawicielami wspominanego już wcześniej stronnictwa opoczyńskiego ${ }^{70}$. Wtargnięcie we wrześniu tegoż roku połączonych sił zbrojnych do stolicy Czech zakończyło się ich pogromem dokonanym przez zbrojnych mieszczan praskich: Stare Miasto dopiero w przyszłości zbliżyć się miało do koalicji ${ }^{71}$. Wcześniejsze wiosenne wydarzenia wykazały natomiast wzrost aktywności politycznej grupy praskich mistrzów uniwersyteckich ${ }^{72}$, coraz wyraźniej przeciwnych nie tylko husyckiej lewicy, lecz także centrum utrakwistycznemu, w którym ideowe przywództwo należało do wpływowego kaznodziei Jana z Rokycan. W późniejszych latach Jan z Př́bramia, Křištan z Prachatic i inne im pokrewne ideowo postaci zbliżą się już jawnie zarówno do czołowych polityków koalicji, jak i do dostojników Kościoła związanych z soborem bazylejskim.

Mówiliśmy poprzednio o raczej sporadycznych przejawach wojskowego współdziałania sił antyradykalnych oraz o postępującym stopniowo procesie politycznego i ideowego zbliżania podyktowanego wspólnym celem, zresztą dość enigmatycznie zarysowanym. Tendencje powyższe należy jednak odnieść do pewnych znaczących nurtów w obu wewnętrznie zróżnicowanych obozach, a nie do ich całości. W obozie katolickim

${ }^{68}$ Zob. S. Bylina, Rewolucja husycka, t. 3, s. 72 n.

${ }^{69}$ Ibidem, t. 2, s. 24 nn. (tamże literatura przedmiotu).

70 Ze świadectw źródłowych zob. Kronika Bartoška z Drahonic, wyd. J. Goll, Fontes Rerum Bohemicarum, t. 5, Praha 1893, s. 597. Zob. P. Čornej, Velké dějiny, t. 5, s. 490.

71 Zob. m.in. P. Čornej, Smolár, Hedvika, Velvar et alii. Poznámky a postřehy ke kapitole z dějín husitské Prahy, w: Pax bella potior. Sborník věnovaný doc. Ph. dr. Rudolfu Andělovi, Liberec 2004, s. 43-62.

${ }^{72}$ Zob. m.in. F.M. Bartoš, op. cit., t. 2, s. 17 nn. 
nie brakło jednostek odżegnujących się od jakiegokolwiek porozumienia z heretykami-husytami. Stanowisko takie głośno wypowiadali zwłaszcza księża emigranci, mający wsparcie części dostojników Kościoła. Wyraziciele takich postaw oczekiwali bądź to decydującego ciosu zadanego wrogom ich wiary i Kościoła przez kolejną wyprawę krzyżową, bądź innych wydarzeń zgubnych dla sił taboryckich i „sierocych”. Hasło szybkiego kompromisowego zakończenia wojny domowej natrafiło na sprzeciw również w środowiskach radykalnych, mimo że do debaty wyznaniowej skłonni byli zasiąść czołowi przywódcy tych stronnictw. Żywy był nurt zbrojnego kontynuowania rewolucji, której nie można zakończyć inaczej niż pełnym zwycięstwem. Nurt ten miał swych rzeczników nie tylko do czasu rozstrzygającej konfrontacji, lecz i później, już po klęsce wojsk polnych, gdy doszły do głosu nieliczne, lecz zdeterminowane wspólnoty walczące z obozem zwycięskim ${ }^{73}$.

W drugiej połowie lat dwudziestych XV w., mimo obiecujących doświadczeń w zakresie współdziałania obozu katolickiego z prawicą kalisznicką, daleko jeszcze było od zawiązania silnej, stabilnej koalicji sił antyradykalnych. Decydujące dla jej powstania były wydarzenia lat 1432-1434, ostateczne zaś uformowanie silnej, stabilnej struktury koalicyjnej zaledwie o kilka miesięcy poprzedziło zbrojną konfrontację dwóch wrogich sobie sił pod Lipanami ${ }^{74}$. Poza omawianymi dalej wydarzeniami i zjawiskami istotna była stopniowa zmiana orientacji wybitnych autorytetów świata katolickiego najsilniej zainteresowanych rozwojem sytuacji w Czechach. W opinii przynajmniej części wpływowych dostojników kościelnych antyhusyckie wyprawy krzyżowe przestały być skuteczną drogą do rozwiązania konfliktu nurtującego zachodnie chrześcijaństwo i do powrotu Czech na łono Kościoła. Od wspierania zbrojnych konfrontacji już od dłuższego czasu odwracał się Zygmunt Luksemburski, widzący w rokowaniach dyplomatycznych i próbie ugody wyznaniowej lepszą drogę do uśmierzenia oporu radykałów i do zamierzonego objęcia tronu czeskiego.

Propozycja ojców soboru bazylejskiego przeprowadzenia katolicko-husyckiej debaty wyznaniowej na forum soborowym została przyjęta w husyckiej Pradze z zadowoleniem, wstępne zaś porozumienie w Chebie, wychodzące naprzeciw postulatom husyckim, otwarło delegacji husyckiej drogę do Bazylei ${ }^{75}$.

73 Zob. S. Bylina, Rewolucja husycka, t. 3, rozdz. „Opór pokonanych”.

${ }^{74}$ Proces formowania się ostatecznego kształtu i programu koalicji rozważa F. Šmahel, Husitská revoluce, t. 3, s. 290 n.

75 S. Bylina, Podróż husytów do Bazylei, Warszawa 2013, s. 38 nn. 
Warto zauważyć, że w delegacji czeskiej udającej się do Bazylei reprezentowane było praskie centrum utrakwistyczne z Janem z Rokycan na czele oraz bractwa: taboryckie (z hetmanem Prokopem Łysym) i „sieroce”, zabrakło natomiast rzeczników skrajnie ugodowego nurtu w utrakwizmie: dotyczyło to kilku znanych mistrzów praskich oraz niektórych wybitnych jednostek z grona husyckiej szlachty ${ }^{76}$. Jest wielce prawdopodobne, że mimo wysunięcia ich kandydatur przez sejm jedni i drudzy, pozostając w kraju, widzieli dla siebie i dla swych kręgów korzystniejsze możliwości porozumienia z Kościołem. Świadczyć o tym może tajne przekazywanie soborowi informacji o Czechach, a także po części niejawne spotkania z legatami bazylejskimi w czasie ich pobytów w Pradze, po zawieszeniu pierwszej, bezskutecznej fazy debaty w Bazylei ${ }^{77}$.

Wspomniane spotkania przedstawicieli prawicy utrakwistycznej z legatami soborowymi odbywały się w cieniu oficjalnych przyjęć wydawanych przez władze miejskie Pragi, uniwersytet i stronnictwa wyznaniowo-polityczne. Choć nie znamy bliżej ich przebiegu, wiemy, że ułatwiły one przekazanie soborowi bazylejskiemu pożądanej przezeń wersji czterech artykułów, nieaprobowanej przez sejm praski. Nieoficjalne porozumienia miały jeszcze inne, istotne znaczenie: zacieśniały więź między gronem mistrzów utrakwistów (przypomnę imiona Jana z Přibramia i Křrištana $z$ Prachatic), a wpływowymi jednostkami z grona wyższej szlachty kalisznickiej. Uczestniczył w nich aktywnie Menhard z Hradca, który, nie zrywając jawnie z taborytami, stawał się jednym z głównych przywódców całej koalicji ${ }^{78}$.

Oblężenie katolickiego Pilzna, ważnego miejskiego ośrodka landfrydu zachodniego, podjęte latem 1433 r. siłami wojsk polnych, będące formą nacisku stronnictw radykalnych na sobór i na czeski obóz katolicki ${ }^{79}$, przyspieszyło mobilizację dotychczasowych uczestników koalicji kalisznicko-katolickiej.

Obóz ugody dążył do swych celów środkami legalnymi, wzbudzającymi zaufanie husyckiej większości. Sejm zwołany do Pragi w listopadzie 1433 r., zwany świętomarcińskim, przy bardzo licznym udziale wyższej szlachty bądź to stanowiącej krąg Menharda z Hradca, bądź to będącej

${ }^{76}$ Ibidem, s. $71 \mathrm{nn}$.

77 Zob. J. Kejř, Mistři pražské univerzity a kněží táborští, Praha 1981, s. 81 n. O nieoficjalnych spotkaniach także S. Bylina, Rewolucja husycka, t. 3, s. 77-79. Zob. jednak przede wszystkim V.V. Tomek, Dějepis města Prahy, t. 4, Praha 1890, s. 575-581.

${ }^{78}$ Jego ówczesną rolę akcentował później Eneasz Sylwiusz Piccolomini: Aeneae Silvii Historia Bohemica, wyd. D. Martinková i in., Praha 1998, s. 156.

79 O oblężeniu Pilzna i jego znaczeniu w ówczesnej sytuacji zob. zwłaszcza M. Polívka, op. cit., s. 258, 372. Zob. też F. Šmahel, Husitská revoluce, t. 3, s. 274 nn. 
sojusznikami husyckiej Pragi, uznał umiarkowaną wersję czterech artykułów za fundament postulowanego pokoju i ładu w państwie. Nie wzbudziło sprzeciwów powołanie stanowiska zarządcy Królestwa Czeskiego i Margrabstwa Morawskiego, które powierzono cenionemu wojownikowi husyckiemu Alešovi Vřeštovskiemu z Rýzemberku ${ }^{80}$.

Sejm świętomarciński powierzył Alešovi Vřeštovskiemu i powołanej przy nim dwunastoosobowej radzie zadanie obrony czterech artykułów oraz wyposażył go w bardzo szerokie uprawnienia wraz z prawem zwoływania sił zbrojnych w potrzebie obrony kraju ${ }^{81}$. W nieznanym nam składzie rady otaczającej zarządcę kraju domyślamy się obecności czołowych przedstawicieli prawicy kalisznickiej, a także rycerza Diviša Bořka z Miletínka, doświadczonego wojownika, zapewne już wówczas upatrywanego na głównego dowódcę sił zbrojnych obozu koalicyjnego.

Przywódcy formującej się struktury koalicyjnej bacznie obserwowali aktualne wydarzenia i ich wpływ na zmieniającą się atmosferę społeczną w kraju. Przedłużające się oblężenie Pilzna, powodujące dramatyczną sytuację obrońców (umiarkowanie wspomaganych przez członków landfrydu), skłaniało do podejmowania działań o istotnym znaczeniu. Dodajmy, że koalicjantom sprzyjało niezadowolenie zubożałej ludności dotkliwie eksploatowanej przez wojska polne (bo jednak one głównie zaopatrywały się kosztem wsi). Bractwa radykalne traciły więc swą wcześniejszą popularność i swój autorytet.

Począwszy od wczesnej wiosny 1434 r. przywódcy koalicyjni, spotykając się ze sobą, podejmowali decyzje o znaczeniu strategicznym. Uczestniczyli w nich panowie katoliccy: członkowie landfrydu pilzneńskiego, Oldřich z Rožemberku lub jego przedstawiciele, inni możni oraz czołowi panowie husyccy na czele z Menhardem z Hradca. Okazją ku takiemu spotkaniu mogło być przyjęcie w bawarskim mieście Cham sum pieniężnych zebranych przez ojców soboru, a przeznaczonych na wsparcie obrony Pilzna ${ }^{82}$. Nie wiemy, kiedy swój akces do koalicji zgłosiło chwiejne

${ }^{80}$ Protokół sejmu świętomarcińskiego: Archiv český, t. 3, nr 5, s. 412-415. O sejmie świętomarcińskim i o powołaniu rządu Aleša Vřeštovskiego zob. J. Válka, Vláda Alše Vřeštovského z Riesenburka. Usili husitů o obsazení politického prostoru zemské obce, „Časopis Matice moravské” 128, 2009, s. 297-323. Zob. też F. Šmahel, Husitská revoluce, t. 3, s. 278 n.; P. Čornej, Velké dějiny, t. 5, s. 600 n.

${ }^{81} \mathrm{O}$ zadaniach powierzonych Alešowi Vřeštovskiemu i jego radzie Archiv český, t. 3 , nr 5, s. 412: „[--] aby napřed cti a chwaly boží, obecního dobrého a uspokojení zemi naších swrchujmenovaných wěrně hleděl [--] a zwlaště čtyř swatých a swtlých prawd w zákoně božím založených a w čtyřech artikulech zawřených".

${ }^{82}$ Zob. na ten temat P. Čornej, Velké dějiny, t. 5, s. 610 n. oraz V. Bystrický, op. cit., s. 313. 
dotąd w swych postawach Stare Miasto Praskie wraz ze swymi szlacheckimi sojusznikami. Jednym z motywów tego akcesu był wzmożony antagonizm staromieszczan z Nowym Miastem. Na Nowym Mieście nastroje fermentu podsycali tamtejsi radykalni kaznodzieje, przeciwnicy ugody z Kościołem, a od pewnego czasu utrzymujący sojusz z Sierotkami.

Stare Miasto zbliżyło się do koalicji z pełnym zaangażowaniem: jej przywódcy mogli liczyć na udział sił staromiejskich w zbrojnej konfrontacji. Hetman „polnych” taborytów Prokop Łysy dostrzegł w ideowym i politycznym zwrocie prażan zdradę obozu husyckiego ${ }^{83}$. Natomiast Zygmunt Luksemburski nie krył swego zadowolenia, widząc w uczestnikach koalicji swych wiernych poddanych, którzy obranymi przez siebie środkami pokonają radykalny husytyzm. W kwietniu $1434 \mathrm{r}$. dzielił się swą satysfakcją z Oldřichem Rožemberkiem, donosząc mu o otrzymanej niedawno wiadomości, zgodnie z którą „panowie czescy i morawscy oraz Stare Miasto Praskie i inni ich sojusznicy są już razem, tak jakby byli jednym człowiekiem, i już w Pradze się zgromadzili""

Wydarzenia wiosennych miesięcy $1434 \mathrm{r}$. stanowiły pasmo sukcesów organizacyjnych i strategicznych koalicji. Złożyły się na nie: powodzenie mobilizacji sprawnie i skutecznie przeprowadzonej przez Aleša Vřeštovskiego, wkroczenie części sił koalicyjnych do Pragi i raczej łatwe wyparcie z niej stawiających zbrojny opór nowomieszczan i Sierotek i w rezultacie wytworzenie sytuacji skłaniającej wojska polne do rezygnacji z oblegania Pilzna. Zatrzymajmy się chwilę przy tym wydarzeniu. Nie tylko odstąpienie od oblężenia katolickiego miasta-warowni, lecz także niefortunny jego przebieg, w trakcie którego nie brakło ani buntu w wojsku taboryckim, ani przejawu zdrady ${ }^{85}$, były symptomami kryzysu sił radykalnych. Natomiast dla ogółu czeskich katolików odzyskanie Pilzna, które zdawało się już być bliskie upadku, stało się radosnym wydarzeniem, wytrwały zaś opór jego wojowników i mieszkańców składnikiem budującej legendy obrońców wiary i Kościoła ${ }^{86}$.

${ }^{83}$ List Prokopa Łysego do czołowego przywódcy Sierotek ks. Prokupka zob. Výbor $z$ české literatury husitské doby, t. 1, wyd. B. Havránek, J. Hrabák, J. Danhelka, Praha 1963, s. 407. Istotny fragment tego listu (w przekładzie polskim): S. Bylina, Rewolucja husycka, t. 2, Warszawa 2015, s. 96.

${ }^{84}$ „A poněvadž jsme zpravení také, že páni čeští a moravští a také Staré Město Prazské i jiná jím příchylná spolu jsú za jeden člověk, a že se v Praze sebrali", Listář a listinář Oldřicha z Rožmberka, t. 1, s. 179.

85 O wydarzeniach tych: F. Šmahel, Husitská revoluce, t. 3, s. 290 nn.; P. Čornej, Velké dějiny, t. 5, s. 599 nn.

${ }^{86}$ Późnym świadectwem tego zjawiska jest utwór Hilariusa Litoměřickiego, Historia civitatis Plznensis; tekst: J. Hejnic, M. Polívka, op. cit., s. 84-136. 
Od początku 1434 r. w dwuwyznaniowej koalicji zaobserwować można było przejawy ideowego zacieśniania jej jedności. Przykład ku temu wyszedł z grona praskiej prawicy utrakwistycznej. Jan z Př́bramia, Kř́šţan z Prachatic i Prokop z Pilzna - uznawani za jej duchowe autorytety - powrócili za pośrednictwem legatów na łono Kościoła, zrywając przez to z obozem reformy. W ślad za nimi swój powierzchowny husytyzm porzuciło kilku czołowych panów świeckich ${ }^{87}$. Menhard z Hradca dzięki temu stał się niewątpliwym już współwyznawcą wojowników katolickich, wraz z którymi miał wyruszyć do rozstrzygającego boju z husytami.

Sukcesem przywódców koalicyjnych, już zdecydowanych na zbrojną konfrontację, było skierowanie wszystkich sił ku Českiemu Brodowi i skłonienie wojsk bractw radykalnych do wymarszu w tym kierunku. Wielka konfrontacja była nieunikniona i chyba nikt po obu stronach nie wierzył w rezultat podejmowanych bez przekonania prób zawarcia rozejmu. $\mathrm{Na}$ rozległe pole położone opodal wsi Lipany przybyli wszyscy znani nam uczestnicy sił koalicyjnych: oddziały czeskiej szlachty kalisznickiej oraz oddziały panów katolickich: najliczniejsze z nich wojsko rožemberskie, chyba najsilniejsze oddziały landfrydu pilzneńskiego, oddziały panów opoczyńskich i wojsko karlštejnskie.

$\mathrm{W}$ dniu 30 maja 1434 r. wojska koalicyjne po długiej i krwawej bitwie położyły kres militarnej potędze wojsk polnych i politycznej potędze stronnictw radykalnych. Wiemy, że wraz ze swymi wojownikami życie stracili czołowi dowódcy taboryccy i „sierocy”88.

W Czechach powstała nowa rzeczywistość, w której wiodące role objęli zwycięzcy. W nowej sytuacji politycznej i w nowym układzie sił koalicja katolicko-kalisznicka jako w miarę jednolita struktura poczęła tracić swe znaczenie i sens. To samo stało się udziałem rządu Aleša Vřeštovskiego, który ustąpił wcześniej, nim tron objął Zygmunt Luksemburski.

\section{Streszczenie}

Artykuł przedstawia szczegółowo działania zbrojne i polityczne obozu katolickiego w Czechach w latach dwudziestych i trzydziestych XV w. skierowane przeciw radykalnym stronnictwom husyckim i ich wojskom. Na wstępie przedstawiono geografię głównych sił obozu katolickiego, usytuowanych w Czechach południowych (domena magnackiego rodu Rožemberków) i zachodnich (tzw. landfryd pilzneński). Prześledzono proces stopniowego formowania się koalicji katolicko-husyckiej

87 S. Bylina, Rewolucja husycka, t. 2, s. 183 (tamże referencje źródłowe).

${ }^{88}$ Z licznych opracowań poświęconych bitwie pod Lipanami przytoczę dwie prace pióra Petra Čorneja, Tajemství ceských kronik, s. 195-251; Lipanská křižovatka, s. 184-204. 
(nurtu umiarkowanego i ugodowego), począwszy od wstępnych porozumień antyradykalnych po stabilną strukturę polityczno-militarną i zwycięstwo w bitwie pod Lipanami (1434).

\section{Reflections on the Counter-Revolution. The Czech Catholic Camp and its Allies in the Fight against Hussite Radicals}

The article presents, in great detail, political and military actions of the Catholic camp in the Kingdom of Bohemia undertaken in the 1420s and 1430s against radical Hussite factions and their armed forces. By way of introduction, the geography of main forces of the Catholic camp is presented, located in southern (a magnate domain of the Rožemberk family) and western regions of Bohemia (the so-called Pilsener Landfriede). A process of gradual formation of the Catholic-Hussite coalition (moderate and compromising factions) is traced, from the initial anti-radical agreements to the stable political and military structure and the victorious Battle of Lipany (1434).

Translated by Grażyna Waluga

\section{Bibliografia}

Bartoš František Michálek, Husitská revoluce, t. 1: Doba Žižková 1415-1426, t. 2: Vlada bratrstev a její pád 1426-1427, Academia, Praha 1965, 1966.

Bylina Stanisław, Rewolucja husycka, t. 1: Przedświt i pierwsze lata, t. 2: Czas chwaty i czas zmierzchu, t. 3: Kontrrewolucja i opór pokonanych, IH PAN, Neriton, Warszawa 2011, 2015, 2016.

Bystrický Václav, Západní Čechy v husitských válkách, Veduta, České Budějovice 2013.

Čornej Petr, Tajemství českých kronik. Cesty k kořenům husitské tradice, Praha-Vyšehrad 1987.

Čornej Petr, Lipanská křižovatka. Přičiny, průběh a historický význam jedné bitvy, Panorama, Praha 1992.

Čornej Petr, Velké dějiny zemí Koruny české, t. 5: 1402-1437, wyd. 2, Paseka, PrahaLitomyšl 2010.

Hejnic Josef, Polívka Miloslav, Plzeň v husitské revoluci, Ústav československých a světových dějin ČSAV, Praha 1987.

Husitské století, red. Pavlina Cermanová, Robert Novotný, Pavel Soukup, Lidové noviny, Praha 2014.

Kadlec Jaroslav, Přehled církevních dějin českých, t. 1, Praha 1977.

Kaminsky Howard, A History of the Hussite Revolution, Berkeley, Los Angeles 1967.

Kavka František, Poslední Lucemburk na českém trüně, Mladá fronta, Praha 1998.

Kejř Jíři, Mistři pražské univerzity a kněží táborští, Univerzita Karlova, Praha 1981.

Kubíková Anna, Oldřich II. z Rožmberka, Veduta, České Budějovice 2004. 
Kubů František, Cheb v době husitské, w: Soudce smluvený v Chebu, Panorama, Cheb [1984].

Macek Josef, Tábor v husitském revolučním hnutí, t. 1-2, Nakladatelství Československé Akademie Věd, Praha 1955.

Rožmberkové. Rod českych velmožůa a jeho cesta dějinami, red. Jaroslav Pánek, NPÚ, ÚOP v Českých Budějovicích, České Budějovice 2011.

Šimůnek Robert, Správní systém šlechtického dominia v pozdně středověkých Čechách. Rožmberská doména 1418-1472, Historický ústav AV ČR, Praha 2005.

Šmahel František, Husitská revoluce, t. 1: Doba vymknutá z kloubů, t. 2: Kořeny české reformace, t. 3: Kronika valečných let, t. 4: Epilog bouřlivého věku, Historický ústav AV ČR, Praha 1993.

Šmahel František, Dějiny Tábora, t. 1, cz. 1-2, Jihočeské nakladatelství, České Budějovice 1989, 1990.

Válka Josef, Zikmund a husité. Jak zakončit (husitskou) revoluci, „Časopis Matice moravské" 128, 2009, s. 3-32.

Válka Josef, Husitská revoluce a první pokusy o restauraci, „Časopis Matice moravské” 130, 2011, s. 3-27.

Biogram: Stanisław Bylina (1936-2017) - mediewista i bohemista, badacz m.in. ruchów heretyckich w średniowieczu, znawca rewolucji husyckiej; wieloletni dyrektor Instytutu Historii PAN w Warszawie. 